\title{
PENGEMBANGAN E-LEARNING FISIKA MENGGUNAKAN PHET (PHYSICS EDUCATIONAL TECHNOLOGY) PADA MATERI POKOK DINAMIKA GERAK LURUS BERBASIS KETERAMPILAN BERFIKIR KRITIS
}

\author{
Zainudin \\ Program Studi Pendidikan Matematika, STKIP PGRI Bangkalan, Madura \\ zainudin@stkippgri-bkl.ac.id
}

\begin{abstract}
Abstrak
Tujuan penelitian ini adalah mengembangkan e-learning fisika menggunakan PhET (Physics Educational Technology) berbasis keterampilan berpikir kritis pada materi pokok dinamika gerak lurus. Kelebihan PhET antara lain memiliki aktivitas perkuliahan (lecture), aktivitas kelompok (group activities), aktivitas pekerjaan rumah (homework activities), dan aktivitas laboratorium (laboratory activities). Pengembangan e-learning fisika pada penelitian ini mengikuti langkahlangkah research and development (R\&D) yang terdiri dari tahap analisis, desain (design), pengembangan (develop) dan implementasi. Perangkat e-learning fisika divalidasi oleh dosen pendidikan fisika. Hasil validasi SAP, modul fisika dan lempar penilaian keterampilan berpikir kritis memiliki kategori sangat layak digunakan dallam pembelajaran. Tahap implementasi yaitu ujicoba e-learning fisika menggunakan PhET pada mahasiswa prodi pendidikan matematika STKIP PGRI Bangkalan semester I tahun ajaran 2016-2017, keterlaksanaan SAP dalam pembelajaran memiliki kategori baik, indikator keterampilan berpikir kritis mahasiswa meningkat dan respon mahasiswa terhadap pembelajaran e-learning fisika menggunakan PhET positif.
\end{abstract}

Kata kunci : pengembangan, e-learning, fisika dasar, simulasi PhET, dan berpikir kritis

\begin{abstract}
This research aims to develop an e-learning physics using PhET (Physics Educational Technology) - based critical thinking skills in the subject matter straight motion dynamics. Excess PhET among others, has activity lecture (lecture), activity groups (group activities), the activity of homework (homework activities), and laboratory activities (laboratory activities). The development of elearning physics in this study followed the steps of research and development $(R \& D)$ comprising the steps of analysis, design (design), development (develop) and implementation. E-learning device physics validated by physics education lecturer. SAP validation results, the modules physics and throw critical thinking skills assessment has categorized as very feasible to use in teaching. Phase the implementation phase is testing e-learning physics using PhET student mathematics education Prodi STKIP PGRI Bangkalan first semester of school year 2016-2017, keterlaksanaan SAP in learning have a good category, indicators of critical thinking skills of students increased and student response to the e-learning physics using PhET positive.
\end{abstract}

Keywords: development, e-learning, basic physics, PhET simulations, and critical thinking skills 


\section{Pendahuluan}

Perkembangan Teknologi Komunikasi dan Informasi (ICT) yaitu software (perangkat lunak) open source (gratis) yang dirancang khusus untuk pembelajaran semakin pesat. PhET (Physics Educational Technology) merupakan salah satu software aplikasi open source pembelajaran sains (fisika, kimia, biologi, kebumian dan matematika) yang tersedia pada https://phet.colorado.edu (Wieman, 2002). PhET adalah simulasi interaktif dengan pendekatan berbasis penelitian, yaitu menghubungkan fenomena kehidupan nyata dengan ilmu yang mendasarinya, sehingga dapat meningkatkan pemahaman dan minat mahasiswa. Hal ini memberi kesempatan kepada dosen menggunakan PhET sebagai laboratorium virtual dalam Kegiatan Belajar Belajar (KBM).

KBM matakuliah fisika pada umumnya dosen menjelaskan konsep dan rumus (persamaan) fisika, kemudian meminta mahasiswa mengerjakan latihan soal pada buku fisika, sementara praktikum fisika sulit dilaksanakan karena keterbatasan alat dan bahan laboratorium. Hal ini, menyebabkan motivasi mahasiswa terhadap matakuliah fisika menurun. Sedangkan capaian pembelajaran lulusan matakuliah fisika menurut kurikulum KKNI mengharapkan mahasiswa dapat menguasai konsep dan prinsip umum fisika dan memanfaatkan kemajuan pengetahuan dan teknologi dalam memecahkan permasalahan fisika serta mampu mengambil keputusan strategis berdasarkan analisis data, dan memberikan petunjuk dalam memilih solusi alternatif.

Berdasarkan kurikulum KKNI tersebut di atas, dosen harus dapat merancang (mendesain) pembelajaran sesuai standar kompetensi lulusan yang mencakup aspek kognitif (pengetahuan), psikomotor (keterampilan) dan afektif (sikap). Pembelajaran menggunakan PhET sebagai laboratorium virtual, dapat meningkatkan pemahaman mahasiswa tentang konsep materi yang abstrak atau materi yang sulit dilakukan eksperimen di laboratorium nyata melalui simulasi laboratorium virtual. Laboratorium virtual PhET memberi kesempatan mahasiswa melakukan eksperimen mengidentifikasi dan mengembangkan hubungan variabel eksperimen, mahasiswa bebas bekerja memanipulasi variabel objek eksperimen dan aman dalam melakukan aktivitas (Mustafa \& Trudel, 2013). Hal ini memberi kesempatan mahasiswa membangun (mengkontruksi) pengetahuannya sendiri dari berbagai informasi (pengalaman belajar) melalui kegiatan membuat hipotesis, menganalisis data, dan membuat kesimpulan, sehingga dapat meningkatkan keterampilan berpikir kritis.

Berdasarkan latar belakang di atas, permasalahan penelitian ini adalah bagaimana hasil pengembangan $e$ learning fisika menggunakan PhET (Physics Educational Technology) pada materi pokok dinamika gerak lurus berbasis keterampilan berfikir kritis. Tujuan penelitian adalah mengembangkan e-learning fisika menggunakan PhET (Physics Educational Technology) pada materi pokok dinamika gerak lurus berbasis keterampilan berfikir kritis.

\section{Metode Penelitian}

Penelitian ini merupakan research and development $(R \& D)$ yaitu mengembangkan e-learning fisika menggunakan $P h E T$ pada materi pokok 
dinamika gerak lurus berbasis keterampilan berpikir kritis.

Pada penelitian ini mengikuti langkah-langkah $R \& D$ Sugiyono yang yang diringkas menjadi 4 tahap (Sugioyo, 2009).

1) Tahap I

Tahap I antara lain mengidentifikasi masalah dan potensi pembelajaran fisika, studi literatur konsep teoritis, langkahlangkah, pendekatan pengembangan $e$ learning dan situs http://phet.colorado.edu.

2) Tahap II

Tahap II antara lain membuat desain blue print e-learning fisika menggunakan PhET sebagai acuan mengembangkan perkuliahan antara lain menentukan tujuan pembelajaran sesuai kurikulum KKNI, memilih strategi pembelajaran (aktivitas perkuliahan, aktivitas tugas kelompok, aktivitas pekerjaan rumah, aktivitas laboratorium) dan penilaian.

3) Tahap III

Tahap III antara lain mengembangkan SAP, modul fisika berbasis keterampilan berpikir kritis menggunakan PhET dan lembar penilaian, kemudian validasi ahli (pakar) untuk mengetahui tingkat kelayakkan.

\section{4) Tahap IV}

Tahap III yaitu ujicoba untuk mengetahui keterlaksaan SAP melalui pengamatan, keterampilan berpikir kritis mahasiswa melalui pre test dan post test dan respon mahasiswa terhadap pembelajaran $e$ learning menggunakan PhET. Penelitian ini menggunakan teknik analisis data deskriptif kualitatif.

\section{Hasil Penelitian dan Pembahasan}

1 Hasil Penilaian Kelayakkan Perangkat E-learning Fisika

Penilaian perangkat e-learning fisika untuk mengetahui kelayakkan perangkat e-learning fisika dalam pembelajaran dilakukan oleh dosen pendidikan fisika. Perangkat e-learning fisika terdiri dari Rencana Pembelajaran Semester (RPS), Satuan Acara Perkuliahan (SAP), modul fisika menggunakan PhET berbasis keterampilan berpikir kritis dan lembar penilaian keterampilan berpikir kritis, dan angket respon mahasiswa.

a. SAP

Hasil penilaian SAP pembelajaran elearning menggunakan PhET disajikan pada tabel 1 di bawah ini.

Tabel 1 Hasil Penilaian SAP pembelajaran e-learning menggunakan PhET

\begin{tabular}{lcll}
\hline \multicolumn{1}{c}{ Aspek Penilaian } & Nilai & \multicolumn{1}{c}{ Kategori } & Reliabilitas \\
\hline Tujuan Pembelajaran & 5,00 & Sangat Layak & $94 \%$ \\
Kegiatan Pembelajaran & 4,00 & Layak & \\
Waktu & 4,00 & Layak & \\
Perangkat Pembelajaran & 4,50 & Sangat Layak & \\
Metode Penyajian & 5,00 & Sangat Layak & \\
Bahasa & 4,00 & Layak & \\
\multicolumn{1}{c}{ Nilai Rerata } & $\mathbf{4 , 4 1}$ & Sangat Layak \\
\hline
\end{tabular}

Tabel 1 di atas menunjukkan bahwa hasil memiliki kategori layak, metode penilaian SAP pembelajaran e-learning menggunakan $\mathrm{PhET}$ meliputi aspek tujuan pembelajaran memiliki kategori sangat layak, kegiatan pembelajaran memiliki kategori layak, waktu memiliki kategori layak, perangkat pembelajaran penyajian memiliki kategori sangat layak, dan bahasa memiliki kategori sangat layak.

Aspek tujuan pembelajaran terdiri atas menuliskan capaian pembelajaran (CP), ketepatan penjabaran dari $\mathrm{CP}$ ke 
sub $\mathrm{CP}$, ketepatan penjabaran dari sub $\mathrm{CP}$ ke indikator, ketepatan penjabaran dari indikator ke Tujuan Pembelajaran (TP) dan perumusan TP. Aspek kegiatan pembelajaran terdiri atas kesesuaian model pembelajaran dengan TP, fasefase (sintaks) model pembelajaran ditulis lengkap dalam SAP, fase-fase (sintaks) memuat urutan kegiatan pembelajaran yang logis, dan fase-fase (sintaks) memuat dengan jelas peran dosen dan peran mahasiswa. Aspek waktu terdiri atas pembagian waktu setiap kegiatan dinyatakan dengan jelas dan kesesuaian waktu dengan kegiatan. Aspek perangkat pembelajaran terdiri atas modul fisika menggunakan PhET berbasis keterampilan berpikir kritis menunjang ketercapaian TP, PhET menunjang ketercapaian TP, butir-butir soal lembar penilaian keterampilan berpikir kritis sesuai dengan TP dan mmodul fisika,
PhET dan LP diskenariokan penggunaannya dalam SAP. Aspek metode penyajian terdiri atas aspek penyajian pembelajaran (demonstrasi, simulasi eksperimen virtual) bermakna bagi mahasiswa dan pengalaman belajar mahasiswa menunjang ketercapaian TP. Aspek bahasa terdiri atas menggunakan kaidah Bahasa Indonesia yang baik dan benar, ketepatan struktur kalimat daan keterkinian referensi.

Hasil perhitungan reliabilitas terhadap lembar validasi SAP sebesar 94\%, hal ini menunjukkan bahwa lembar validasi SAP yang digunakan adalah reliabel.

\section{b. Modul Fisika Menggunakan PhET}

Hasil penilaian modul fisika menggunakan PhET berbasis keterampilan berpikir kritis disajikan pada tabel 2 .

Tabel 2 Hasil Penilaian Modul Fisika Menggunakan PhET

\begin{tabular}{lllc}
\hline Aspek Penilaian & Nilai & Kategori & Reliabilitas \\
\hline Isi & 5,00 & Sangat Layak & $86 \%$ \\
Penyajian & 4,50 & Sangat Layak & \\
Kegrafikan & 4,00 & Layak & \\
Bahasa & 4,00 & Layak & \\
Keterampilan Berpikir Kritis & 4,00 & Layak & \\
\multicolumn{1}{c}{$\quad$ Nilai Rerata } & 4,33 & Sangat Layak & \\
\hline
\end{tabular}

Tabel 2 menunjukkan bahwa aspek penilaian terdiri atas aspek kelayakkan isi memiliki kategorisangat layak, kelayakkan penyajian memiliki kategori sangat layak, kelayakkan kegrafikan memiliki kategori layak, penilaian bahasa memiliki kategori layak, dan penilaian keterampilan berpikir kritis memiliki kategori layak.

Indikator kelayakkan isi antara lain kesesuaian dengan kompetensi kurikulum KKNI, keakuratan materi, pendukung materi pembelajaran dan kemutakhiran materi. Indikator kelayakkan penyajian antara lain teknik penyajian, pendukung penyajian, penyajian pembelajaran dan kelengkapan penyajian. Indikator kelayakkan kegrafikan antara lain ukuran modul, desain sampul modul (cover) dan isi modul. Indikator penilaian bahasa antara lain lugas, komunikatif, dialogis dan interaktif, kesesuaian dengan tingkat perkembangan mahasiswa, keruntutan dan keterpaduan alur pikir, dan penggunakan istilah dan simbol. Indikator penilaian keterampilan berpikir kritis adalah karakteristik keterampilan berpikir kritis.

Hasil perhitungan reliabilitas terhadap lembar validasi modul fisika menggunakan PhET berbasis 
keterampilan berpikir kritis sebesar $86 \%$, hal ini menunjukkan bahwa lembar validasi modul fisika yang digunakan adalah reliabel.

c. Lembar Penilaian Keterampilan Berpikir Kritis
Hasil penilian lembar penilaian keterampilan berpikir kritis disajikan pada tabel 3 .

Tabel 3 Hasil Penilaian LP Keterampilan Berpikir Kritis

\begin{tabular}{lclc}
\hline \multicolumn{1}{c}{ Aspek Penilaian } & Nilai & Kategori & Reliabilitas \\
\hline Materi & 4,50 & Sangat layak & $94 \%$ \\
Konstruksi & 4,00 & Layak & \\
Bahasa & 4,00 & Layak &
\end{tabular}

Nilai Rerata

4,16 Sangat Layak

Tabel 3 di atas menunjukkan bahwa aspek penilaian lembar penilaian keterampilan berpikir kritis terdiri dari aspek materi memiliki kategori sangat layak, konstruksi memiliki kategori layak, dan bahasa memiliki kategori layak.

Indikator penilaian aspek materi antara isi materi sesuai $\mathrm{CP}$ dan isi materi sesuai dengan mahasiswa. Indikator penilaian aspek konstruksi terdiri atas rumusan kalimat soal atau pertanyaan menggunakan kata tanya atau perintah yang menuntut jawaban terurai, ada petunjuk yang jelas tentang cara mengerjakan soal, ada pedoman penskoran, gambar, grafik, tabel, diagram jelas . Indikator penilaian aspek penilaian bahasa terdiri atas rumusan kalimat soal komunikatif, butir soal menggunakan bahasa yang benar dan baik, rumusan soal tidak menggunakan kalimat yang menimbulkan penafsiran ganda atau salah pengertian, rumusan soal tidak mengandung kata-kata yang dapat menyinggung perasaan mahasiswa.

Hasil perhitungan reliabilitas terhadap lembar penilaian keterampilan berpikir kritis sebesar 94\%, menunjukkan bahwa lembar penilaian keterampilan berpikir kritis yang digunakan adalah reliabel.

2 Hasil Ujicoba Pembelajaran Elearning Fisika Menggunakan PhET

Hasil ujicoba pembelajaran e-learning fisika menggunakan PhET untuk mengetahui efektifitas dalam pembelajaran antara lain keterlaksanaan pembelajaran, keterampilan berpikir kritis dan respon mahasiswa.

a. Keterlaksanaan Pembelajaran Elearning Menggunakan PhET

Hasil pengamatan keterlaksanaan pembelajaran e-learning fisika menggunakan PhET disajikan pada tabel 4.

Tabel 5. 4 Pengamatan Keterlaksanaan Pembelajaran E-learning

\begin{tabular}{lccc}
\multicolumn{1}{c}{ Aspek yang diamati } & Nilai & Kategori & Reliabilitas \\
\hline $\begin{array}{l}\text { Fase 1 } \\
\begin{array}{l}\text { Menyampaikan tujuan pembelajaran dan } \\
\text { mempersiapkan mahasiswa untuk }\end{array}\end{array}$ & & & $90 \%$ \\
$\begin{array}{l}\text { belajar serta memotivasi mahasiswa } \\
\text { dengan mengaitkan materi dengan }\end{array}$ & 3,5 & Baik & \\
$\begin{array}{l}\text { kehidupan sehari-hari. } \\
\text { Fase 2 }\end{array}$ & & & \\
Menyampaikan materi dinamika gerak & 4.0 & Baik & \\
\cline { 2 - 3 }
\end{tabular}




\begin{tabular}{lccc}
\hline \multicolumn{1}{c}{ Aspek yang diamati } & Nilai & Kategori & Reliabilitas \\
\hline $\begin{array}{l}\text { lurus dan mendemostrasikan } \\
\text { menggunakan simulasi PhET }\end{array}$ & & & \\
$\begin{array}{l}\text { Fase } \mathbf{3} \\
\text { Membimbing mahasiswa melakukan } \\
\text { eksperimen virtual menggunakan PhET } \\
\text { dipandu modul e-learning fisika }\end{array}$ & 3,5 & Baik & \\
$\begin{array}{l}\text { Fase } \mathbf{4} \\
\text { Meminta mahasiswa untuk }\end{array}$ & & \\
$\begin{array}{l}\text { mempresentasikan hasil eksperimen } \\
\text { virtual di depan kelas dan memberi } \\
\text { umpan balik }\end{array}$ & 3,0 & Cukup \\
$\begin{array}{l}\text { Fase 5 } \\
\begin{array}{l}\text { Meminta mahasiswa belajar mandiri } \\
\text { dengan mengerjakan soal pada modul } \\
\text { fisika }\end{array}\end{array}$ & 3,5 & Baik \\
\hline
\end{tabular}

Tabel 4 menunjukkan bahwa penilaian keterlaksanaan SAP pada fase 1 yaitu dosen menyampaikan tujuan pembelajaran dan memotivasi mahasiswa dengan mengaitkan materi dinamika gerak lurus dalam kehidupan sehari-hari kategori .baik. Fase 2 yaitu dosen membangkitkan pengetahuan awal mahasiswa tentang konsep dinamika gerak lurus melalui diskusi dan dosen mendemostrasikan langkah-langkah menggunakan PhET kepada mahasiswa kategori baik. Fase 3 dosen membimbing mahasiswa melakukan eksperimen virtual menggunakan PhET Ramp: Forces and Motion dipandu oleh modul e-learning fisika kategori baik. Fase 4 yaitu dosen meminta mahasiswa mempresentasikan hasil eksperimen virtual di depan kelas dan memberi umpan balik kategori cukup. Fase 5 yaitu dosen meminta mahasiswa belajar mandiri dengan mengerajakan soal pada modul e-learning fisika kategori baik dan reliabilitas Lembar Pengamatan Keterlaksanaan SAP sebesar 94\%.

Hasil pengamatan keterlaksanaan pembelajaran e-learning fisika menggunakan PhET pada fase 1 yaitu dosen menyampaikan tujuan pembelajaran dan memotivasi mahasiswa dengan mengaitkan materi dinamika gerak lurus dalam kehidupan sehari-hari kategori sangat layak. Fase 2 yaitu dosen membangkitkan pengetahuan awal mahasiswa tentang konsep dinamika gerak lurus melalui diskusi dan dosen mendemostrasikan langkah-langkah menggunakan PhET kepada mahasiswa kategori layak. Fase 3 dosen membimbing mahasiswa melakukan eksperimen virtual menggunakan PhET Ramp: Forces and Motion dipandu oleh modul e-learning fisika kategori layak. PhET memberi kesempatan mahasiswa melakukan eksperimen untuk mengidentifikasi dan mengembangkan hubungan variabel eksperimen, mahasiswa bebas bekerja memanipulasi variabel objek eksperimen dan aman dalam melakukan aktivitas (Mustafa \& Trudel, 2013). Hal ini melatih keterampilan berpikir kritis mahasiswa melalui kegiatan membuat rumusan masalah, membuat hipotesis, merancang suatu eksperimen dan menarik kesimpulan berdasarkan hasil eksperimen yang dilakukan. Mahasiswa mencari sendiri jawaban dari pertanyaan mahasiswa dan membuktikan secara 
langsung melalui eksperimen. Simulasi interaktif PhET dapat sangat meningkatkan efektifitas pembelajaran, jika interaksi mahasiswa dengan simulasi berdasarkan pertanyaan mahasiswa sendiri(Adams, et al., 2008). Mahasiswa mengkonstruksi sendiri konsep melalui pengalaman kegiatan eksperimen, sehingga pembelajaran menjadi bermakna (meaningful learning). Kegiatan merancang eksperimen simulasi dipandu modul e-learning fisika dapat siswa mengeksplorasi menemukan konsep dan meningkatkan keterampilan proses sains melalui simulasi interaktif (Chamberlain, Lancaster, Parson, \& Perkins, 2014). Pendekatan pembelajaran inquiry dengan simulasi interaktif meningkatkan efektifitas pembelajaran dan mengembangkan pemahaman konseptual mahasiswa dalam fisika(Fan,
2015). Pembelajaran menggunakan simulasi PhET memberi kesempatan kepada mahasiswa untuk mengeksplor pengetahuan dengan menghubungkan fenomena nyata dengan sains sehingga dapat meningkatkan pemahaman konsep fisika(Perkins, et al., 2006). Fase 4 yaitu dosen meminta mahasiswa mempresentasikan hasil eksperimen virtual di depan kelas dan memberi umpan balik kategori sangat layak. Fase 5 yaitu dosen meminta mahasiswa belajar mandiri dengan mengerajakan soal pada modul e-learning fisika kategori layak

b. Hasil Tes Keterampilan Berpikir Kritis

Hasil keterampilan berpikir kritis mahasiswa pada pre test dan post test ditunjukkan pada gambar grafik 1 .

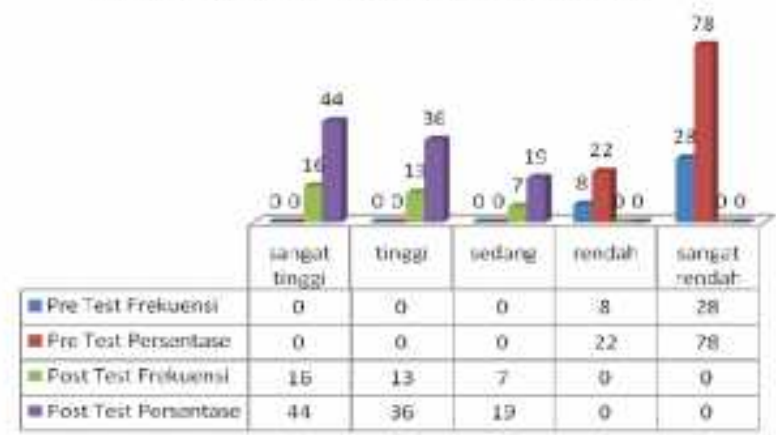

Gambar 1 Hasil Pre Test dan Post Test Keterampilan Berpikir Kritis

Gambar 1 menunjukkan bahwa keterampilan berpikir kritis mahasiswa pada pre test memiliki kategori sangat rendah dan rendah dengan presentase 78 $\%$ dan $22 \%$, sedangkan keterampilan berpikir kritis mahasiswa pada post test memiliki kategori sangat tinggi, tinggi dan sedang dengan persentase $44 \%, 36 \%$ dan $19 \%$. Hal ini membuktikan bahwa pembelajaran e-learning fisika menggunakan PhET dapat meningkatkan keterampilan berpikir kritis.
Ujicoba pembelajaran e-learning menggunakan PhET mahasiswa dapat melakukan aktivitas laboratorium (laboratory activities) yaitu melakukan eksperimen virtual menggunakan PhET Ramp: Forces and Motion dipandu modul fisika. Mahasiswa merancang eksperimen simulasi hukum pertama newton dan kedua newton dan mengkontruksi (menemukan) sendiri konsep melalui kegiatan eksperimen, trial and error dengan memanipulasi variabel-variabel eksperimen, 
memprediksi pengaruh dari manipulasi variabel sehingga membangkitkan rasa ingin tahu, sifat kreatif dan kritis mahasiswa.

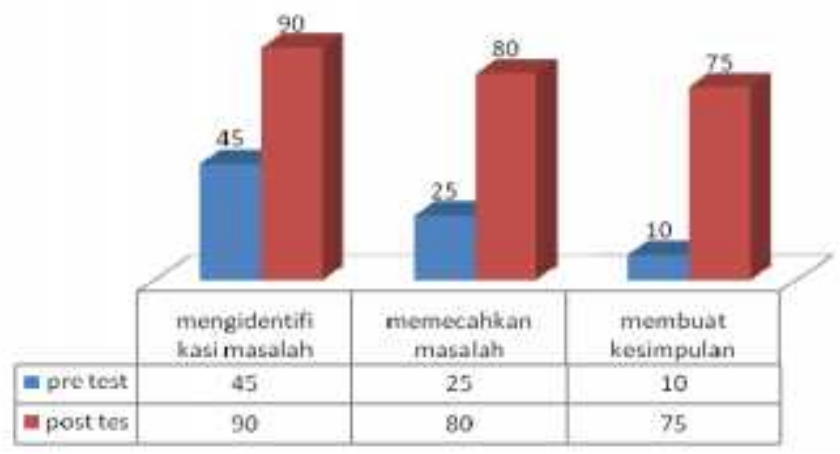

Gambar 2 Indikator Keterampilan Berpikir Kritis pada Pre Test dan Post Test

Gambarl 2 menunjukkan bahwa indikator keterampilan berpikir kritis mengidentifikasi masalah memiliki kategori sangat tinggi, indikator memecahkan masalah memiliki kategori tinggi dan indikator membuat kesimpulan memiliki kategori sedang.

Indikator keterampilan berpikir kritis mengidentifikasi masalah yaitu mahasiswa diminta menggambarkan diagram benda bebas pada sebuah balok pada permukaan bidang datar dan bidang miring yaitu menggambar gaya-gaya yang bekerja pada balok dengan memberi penjelasan, sehingga mahasiswa dapat mengidentifikasi variabel gaya (F) dan percepatan (a) yang diketahui dan variabel yang ditanya. Indikator keterampilan berpikir kritis mengidentifikasi masalah pada umumnya mahasiswa dapat menjawab dengan tepat yaitu mahasiswa dapat menentukan variabel - variabel yang diketahui dan variabel-variabel yang ditanya pada suatu benda pada permukaan bidang datar dan bidang miring dengan memberi penjelasan memiliki kategori sangat tinggi.

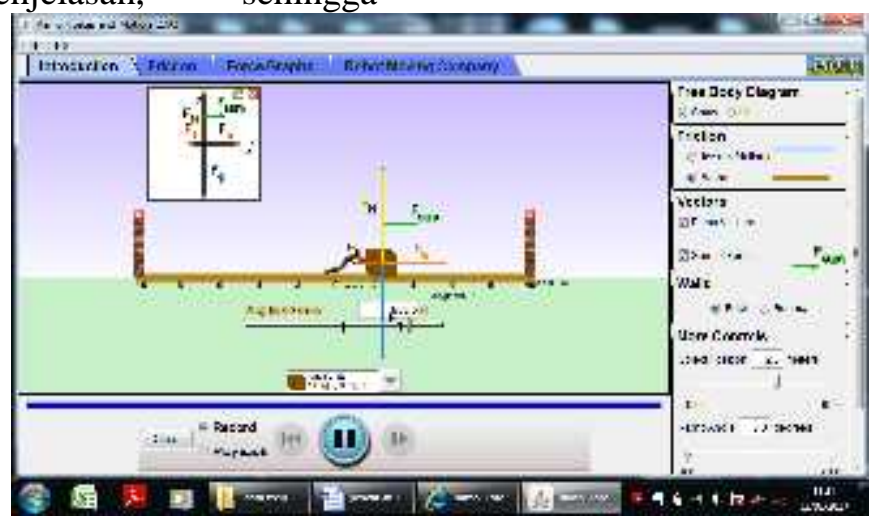

Gambar 3 Diagram Benda Bebas suatu Balok pada Bidang Datar Menggunakan PhET Ramp: Forces and Motion 
Gambar 3 menunjukkan diagram benda bebas suatu balok pada permukaan bidang datar menggunakan PhET Ramp : Forces and Motion. Gaya - gaya yang bekerja pada suatu benda (sumbu y) yaitu gaya normal $\left(\mathrm{F}_{\mathrm{N}}\right)$ dan gaya berat $\left(\mathrm{F}_{\mathrm{w}}\right)$ dapat ditampilkan dengan mengklik Show pada Free Body Diagram. Gaya gaya dan resultan gaya yang bekerja pada suatu benda (sumbu $\mathrm{x}$ ) dapat ditampilkan dengan memberi ceck box pada Force Vectors dan Sum of Forces dan mengklik balok kemudian menggeser ke kanan atau kiri (mendorong).

Indikator keterampilan berpikir kritis memecahkan masalah yaitu mahasiswa diminta menentukan besar gaya $\mathrm{F}$ pada permukaan bidang datang ketika balok tepat akan bergerak, ketika balok bergerak dengan percepatan berbedabeda dan ketika balok tepat akan berhenti dan menentukan percepatan balok ketika balok meluncur ke bawah jika $\theta=30^{\circ}$ dan $\theta=45^{\circ}$. Indikator keterampilan berpikir kritis memecahkan masalah pada umumnya mahasiswa dapat menjawab dengan tepat, tetapi ada beberapa mahasiswa kurang tepat dalam menggunakan persamaan hukum newton yaitu menentukan resultan gaya yang bekerja pada suatu benda jika gaya gesek diabaikan atau tidak, menentukan hubungan persamaan resultan gaya pada sumbu $\mathrm{x}$ dan sumbu y sehingga memiliki kategori tinggi.

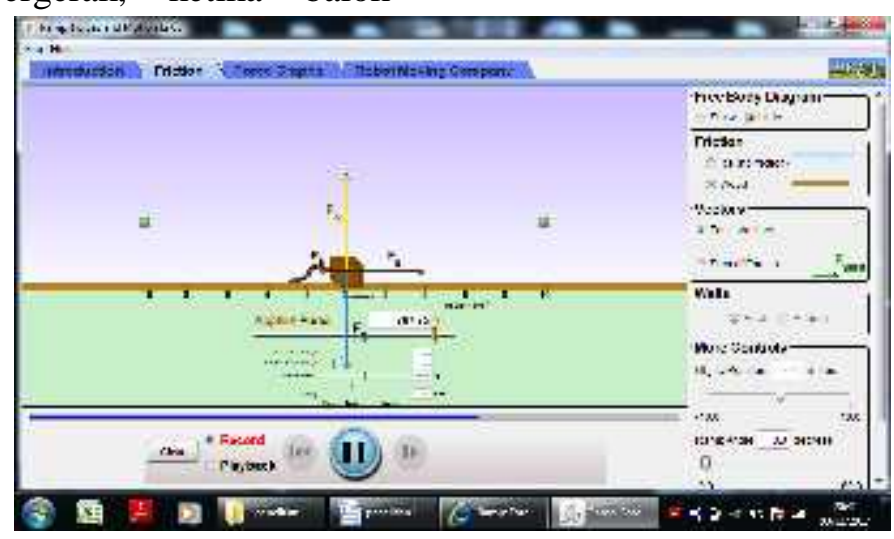

Gambar 4 Balok Bergerak pada Permukaan Bidang Datar

Gambar 4 menunjukkan simulasi sebuah balok pada permukaan datar menggunakan PhET Ramp: Forces and Motion. Mahasiswa dapat memanipulasi massa benda dengan menggeser pada Object Mass dari interval $1 \mathrm{~s} / \mathrm{d} 200 \mathrm{~kg}$. Mahasiswa juga dapat memanipulasi koefisien gesek statik ( $\mathrm{s}$ ) dan koefisien gesek kinetik ( k) dengan menggeser Static Friction dan Kinetic Friction dari interval $0 \quad \mathrm{~s} / \mathrm{d} \quad 2$, sehingga dapat menentukan tingkat kekasaran suatu permukaan (gaya gesek diabaikan atau tidak). Hal ini memberi kesempatan kepada mahasiswa untuk menentukan besarnya gaya yang diperlukan oleh suatu benda yang akan tepat bergerak, bergerak dengan percepatan berbedabeda, benda akan tepat berhenti (jika gaya gesek diabaikan atau tidak) dengan mengklik benda dan menggeser ke kanan atau ke kiri.

Indikator keterampilan berpikir kritis membuat kesimpulan yaitu mahasiswa memberi kesimpulan berdasarkan hasil dari penyelesaian masalah yaitu menentukan bagaimana hubungan gaya dengan percepatan, massa benda dengan 
percepatan, bagaimana hubungan gaya e-ISSN: 2527-7634

gesek terhadap percepatan, dan bagaimana sudut kemiringan dengan percepatan memiliki kategori sedang, hal ini mahasiswa tidak tepat membuat kesimpulan.

c. Respon Mahasiswa

Hasil respon mahasiswa terhadap pembelajaran e-learning menggunakan PhET dapat disajikan pada tabel 5.5 sebagai berikut.

Tabel 5 Hasil Respon Mahasiswa terhadap Pembelajaran E-learning

\begin{tabular}{|c|c|c|c|c|c|c|c|}
\hline \multirow[t]{2}{*}{ No } & \multirow{2}{*}{ Pernyataan } & \multicolumn{4}{|c|}{$\begin{array}{l}\text { Jumlah Jawaban } \\
\text { Responden }\end{array}$} & \multirow[t]{2}{*}{ Skor } & \multirow{2}{*}{ Keterangar } \\
\hline & & STS & TS & $\mathrm{S}$ & SS & & \\
\hline
\end{tabular}

Pembagian kelompok

belajar pembelajaran e-

learning menggunakan

1. PhET memberi kesempata saya untuk bertanggung atas ang ,kiocadgota kelompok belajar Simulasi PhET memberi kesempatan saya

2. berinteraksi langsung dengan komputer maupun

$\begin{array}{llllll}0 & 1 & 4 & 31 & 96 & \begin{array}{l}\text { Sangat } \\ \text { Setuju }\end{array}\end{array}$
secara online

Aktivitas mahasiswa dalam modul e-learning fisika

3. membuat saa harus
menggunakan simulasi menggunakan PhET Simulasi PhET membuat konsep dinamika gerak

4. lurus sesuai dengan pengalaman saya dalam kehidupan sehari-hari Simulasi PhET memberi kesempatan saya

5. melakukan eksperimen menggunakan nilai variabel

$\begin{array}{llllll}0 & 1 & 0 & 35 & 99 & \begin{array}{l}\text { Sangat } \\ \text { Setuju }\end{array}\end{array}$
yang berbeda dengan mudah Simulasi PhET memberi

6. kesempatan saya berpikir secara logis, memprediksi

$\begin{array}{llllll}0 & 4 & 25 & 7 & 77 & \text { Setuju }\end{array}$
dan memecahkan masalah Simulasi PhET memberi

7. kesempatan saya belajar 0 $\begin{array}{llllll}0 & 3 & 23 & 10 & 80 & \begin{array}{l}\text { Sangat } \\ \text { Setuju }\end{array}\end{array}$ learning fisika 


\begin{tabular}{|c|c|c|c|c|c|c|c|}
\hline \multirow{2}{*}{ No } & \multirow{2}{*}{ Pernyataan } & \multicolumn{4}{|c|}{$\begin{array}{l}\text { Jumlah Jawaban } \\
\text { Responden }\end{array}$} & \multirow{2}{*}{ Skor } & \multirow{2}{*}{ Keterangan } \\
\hline & & STS & $\mathrm{TS}$ & $\mathrm{S}$ & SS & & \\
\hline 8. & $\begin{array}{l}\text { Modul e-learning fisika } \\
\text { memberi kesempatan saya } \\
\text { melakukan penilaian diri } \\
\text { (self evaluation) }\end{array}$ & 2 & 3 & 22 & 9 & 76 & Setuju \\
\hline 9. & $\begin{array}{l}\text { Penilaian hasil belajar } \\
\text { pembelajaran e-learning } \\
\text { menggambarkan } \\
\text { pemahaman saya tentang } \\
\text { materi dinamika gerak lurus }\end{array}$ & 0 & 1 & 29 & 6 & 78 & Setuju \\
\hline 10. & $\begin{array}{l}\text { Pembelajaran e-learning } \\
\text { menggunakan PhET } \\
\text { sebagai alternatif metode } \\
\text { pembelajaran fisika masa } \\
\text { kini }\end{array}$ & 1 & 0 & 28 & 7 & 78 & Setuju \\
\hline
\end{tabular}

Tabel 5.5 menunjukkan bahwa respon mahasiswa terhadap suasana belajar menggunakan simulasi PhET yang terdapat pada butir angket 1 dan 2 merasa sangat setuju. Butir angket 3 dan 7 menunjukkan bahwa respon mahasiswa terhadap pembelajaran e-learning menggunakan PhET menjadi aktif sangat setuju. Butir 4 menunjukkan bahwa respon mahasiswa terhadap pembelajaran e-learning menggunakan PhET dapat meningkatkan pemahaman konsep materi dinamika gerak lurus sangat setuju. Butir angket 5 dan 6 menunjukkan bahwa respon mahasiswa terhadap pembelajaran e-learning menggunakan PhET melatih mahasiswa keterampilan berpikir kritis setuju. Butir 8 dan 9 menunjukkan bahwa respon mahasiswa terhadap pembelajaran e-learning menggunakan PhET dapat melatih kemampuan menilai kemampuan diri setuju. Butir angket 10 menunjukkan bahwa respon mahasiswa tehadap metode pembelajaran e-learning menggunakan PhET sebagai alternatif pembelajaran pada era perkembangan teknologi yang semakin pesat setuju.

Berdasarkan data angket respon mahasiswa tersebut dapat disimpulkan bahwa respon mahasiswa setuju terhadap pembelajaran e-learning fisika menggunakan PhET dapat meningkatkan keterampilan berpikir kritis dengan tingkat persetujuan $83,3 \%$.

\section{Kesimpulan dan Saran}

Berdasarkan temuan hasil penelitian, dapat disimpulkan bahwa pembelajaran e-learning fisika menggunakan PhET (Physics Educational Technology) pada materi pokok dinamika gerak lurus berbasis keterampilan berpikir kritis layak dan efektif digunakan dalam proses pembelajaran.

\section{Daftar Pustaka}

Abrami, P. C., Bernard, R. M., Borokhovski, E., Wade, A., Surkes, M. A., Tamim, R., et al. (2008). Instructional Interventions Affecting Critical Thinking Skill and Dispositions: A Stage 1 Meta Analysis. Educational Research, 78 (4), 1102-1134. 
Adams, W. K., Reid, S., LeMaster, R., McKagan, S. B., Perkins, K. K., Dubson, M., et al. (2008). A Study of Educational Simulations Part I Engagement and Learning. Journal of Interactive Learning Research , 19 (3), 397-419.

Bloom, B. S. (1956). Taxonomy of Educational Objectives. The Classification of Educational Goals. New York: David McKay Company.

Borich, G. D. (1994). Observation Skills for Effective Teaching. . USA: The University of Texas.

Chamberlain, J. M., Lancaster, K., Parson, R., \& Perkins, K. K. (2014). How guidance affects student engagement with an interactive simulation. Chemistry Education Research and Practice, 15 (4), 628-638.

Fan, X. (2015). Effectiveness of an inquiry-based learning using interactive simulations for enhancing students' conceptual understanding in physics. $\mathrm{PhD}$ Thesis, The University of Queensland, School of Education, Queensland.

Ghirardini, B. (2011). E-learning methodologies A guide for designing and developing $e$ learning courses. (B. Shapiro, Penyunt.) Viale delle Terme, Caracalla, Roma: Policy and Support Branch.

Giancoli, D. C. (2001). Fisika (Kelima ed.). Jakarta: Erlangga.

Giancoli, D. C. (2001). Physics Principles with Aplication. New Jersey: Prentice Hall International. James, B. (2015). The Learning Centre The University of Sydney. Dipetik Mei Senin, 2016, dari Orientation Lecture Series: Learning To Learn Developing critical thinking skills:
e-ISSN: 2527-7634

http://sydney.edu.au/stuserv/docu ments/learning_center/critical.pdf

Mustafa, M. I., \& Trudel, L. (2013). The Impact of Cognitive Tools on the Development of the Inquiry Skills of High School Students in Physics. International Journal of Advanced Computer Science and Applications , 4 (9), 128.

Perkins, K., Adams, W., Dubson, M., Finkelstein, N., Reid, S., Wieman, C., et al. (2006). PhET: Interactive Simulations for Teaching and Learning Physics. American Association of Physics Teachers .

Riduwan. (2006). Metode dan Menyusun Tesis. Bandung: Alfabeta.

Sugioyo. (2009). Metode Penelitian Kuantitatif Kualitatid dan $R \& D$. Bandung: Alfabeta.

Wieman, C. (2002). PhET Interactive Simulations. (University of Colorado) Dipetik Oktober Rabu, 2016, dari https://phet.colorado.edu: https://phet.colorado.edu

Zemansky, S. (1994). Fisika Untuk Universitas 1 Mekanika, Panas dan Bunyi. Bandung: Binacipta. 